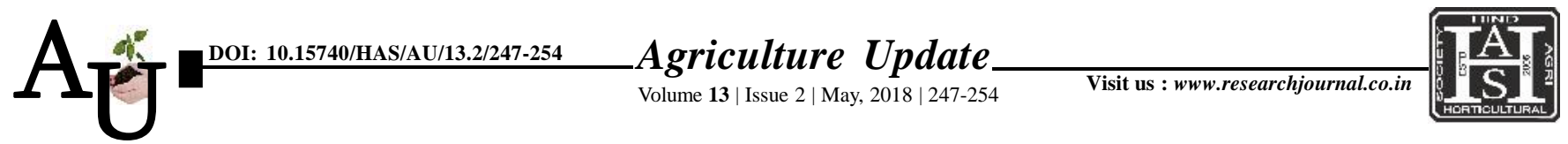

[ e ISSN-0976-6847

\title{
A Review : \\ Soil as an infinitive source to meet the challenges of mankind
}

Article Chronicle:
Received :
19.03.2018;
Accepted:
29.04.2018

Key Words :

Soil, Soul,

Perspectives,

Dynamic, Inert, Dirt,

Stimulus, System,

Brain, Imprint, Mother

Earth, Scavengers,

Capacity,

Responsibility,

Forbearance, Karma,

Conservation

Author for correspondence :

Rajeshwar Malavath

Department of Soil

Science and Agricultural

Chemistry, College of

Agriculture, Professor

Jayashankar Telangana

State Agricultural

University,

Rajendranagar,

Hyderabad (Telangana)

India

Email:rajeshoct31naik@

pjtsau.edu.in

See end of the article for

authors' affiliations

\section{Rajeshwar Malavath and B. Kranthi Kumar}

SUMMARY : Soil is a dynamic natural body that is essential to life; Water movement, water quality, land use, and vegetation productivity all have relationships with soil. Soil as a living dynamic system has been compared to human beings which is the basis and the soul of infinite life. Everything begins in the soil and finally ends in it. Soil is a purifier and acts as a scavenger. The importance of soil conservation, the need to conserve and preserve with respect to the soil has been elaborated in this article in relation to human kind on the way to give emphasis to protect soil to create healthy soil for healthy life.

How to cite this article : Malavath, Rajeshwar and Kumar, B. Kranthi (2018). Soil as an infinitive source to meet the challenges of mankind. Agric. Update, 13(2): 247-254; DOI : 10.15740/HAS/AU/13.2/247-254. Copyright@2018: Hind Agri-Horticultural Society. 